\title{
Article \\ Gender Differences in Low-Molecular-Mass-Induced Acute Lung Inflammation in Mice
}

\author{
Yifang Xie ${ }^{1}{ }^{1}$, Dehui Xie ${ }^{1},{\text { Bin } \mathrm{Li}^{1}}^{1}$ and Hang Zhao ${ }^{1, *}$ \\ Collaborative Innovation Center of Yangtze River Delta Region Green Pharmaceuticals, \\ Zhejiang University of Technology, Hangzhou 310014, China; 2111823025@zjut.edu.cn (Y.X.); \\ 2111923051@zjut.edu.cn (D.X.); 2111923049@zjut.edu.cn (B.L.) \\ * Correspondence: zhaohang@zjut.edu.cn; Tel.: +86-0571-88320494
}

check for updates

Citation: Xie, Y.; Xie, D.; Li, B.; Zhao, H. Gender Differences in Low-Molecular-Mass-Induced Acute Lung Inflammation in Mice. Int. J. Mol. Sci. 2021, 22, 419. https:// doi.org/10.3390/ijms22010419

Received: 15 November 2020 Accepted: 31 December 2020 Published: 3 January 2021

Publisher's Note: MDPI stays neutral with regard to jurisdictional clai$\mathrm{ms}$ in published maps and institutional affiliations.

Copyright: (C) 2021 by the authors. Licensee MDPI, Basel, Switzerland. This article is an open access article distributed under the terms and conditions of the Creative Commons Attribution (CC BY) license (https:// creativecommons.org/licenses/by/ $4.0 /)$.
Abstract: Gender differences in pulmonary inflammation have been well documented. Although low molecular mass hyaluronan (LMMHA) is known to trigger pulmonary lung inflammation, sex differences in susceptibility to LMMHA are still unknown. In this study, we test the hypothesis that mice may display sex-specific differences after LMMHA administration. After LMMHA administration, male mice have higher neutrophil, cytokine, and chemokine counts compared to that of their female counterparts. Additionally, Ovariectomized (OVX) mice show greater LMMHA-induced inflammation compared to that of mice with intact ovaries. Injections of OVX mice with $17 \beta$-estradiol can decrease inflammatory responses in the OVX mice. These results show that ovarian hormones regulate LMMHA induced lung inflammation.

Keywords: low-molecular-mass hyaluronan (200 kDa); acute lung inflammation; gender differences; $17 \beta$-estradiol

\section{Introduction}

Hyaluronan, or hyaluronic acid (HA), is a major component of an extracellular matrix with a structure made up of polymeric disaccharides D-Glucuronic acid and N-acetyl-Dglucosamine A linked by glucuronic acid bonds [1]. Rapid degradation of hyaluronic acid produces low-molecular-mass HA (LMMHA), which has pro-inflammatory effects and acts as an intracellular signal molecule in inflammation [2]. Patients with acute respiratory distress syndrome, idiopathic pulmonary fibrosis, chronic obstructive pulmonary disease, and asthma have significantly increased LMMHA [3-6].

LMMHA upregulates adhesion molecules in endothelial cells and induces production of pro-inflammatory cytokines in airway epithelial cells [7]. In vitro studies have shown that in response to LMMHA stimulation, macrophages are the main effector cells in producing pro-inflammatory chemokines and cytokines [7]. Neutrophils also play key roles in inflammatory pulmonary diseases [8,9]. Previously, we reported that intratracheal administration of LMMHA $(200 \mathrm{kDa})$ causes neutrophil infiltration in mice lungs, which is associated with an increase in interleukin-6 (IL-6), chemokine (C-X-C motif) ligand 1 (CXCL-1), tumor necrosis factor- $\alpha$ (TNF- $\alpha)$, and chemokine (C-X-C motif) ligand 2 (CXCL-2) levels $[10,11]$. Our previous study suggests that phosphoinositide 3-kinase (PI3K)/Akt1 signaling plays a key role in LMMHA (200 kDa)-induced lung inflammation [12].

Both adults and children have sex-specific differences in organ injury. Morbidity and incidence of acute lung injury are higher in males [13-16]. Although the gender difference in pulmonary response is obvious in different animal models of experimental lung injury [17], it is unknown whether there is a difference in inflammatory responses between males and females after intratracheal administration of hyaluronan $(200 \mathrm{kDa})$. 


\section{Results}

\subsection{Plasma Estradiol Concentration}

Plasma estradiol concentration was measured in female mice (proestrus, estrus, metaestrus, and diestrus) and in Ovariectomized (OVX) mice and 17 $\beta$-estradiol (E2) treated OVX mice. Plasma estradiol is at its maximum in the proestrus stage and reaches levels of $\sim 60 \mathrm{pg} / \mathrm{mL}$, but is reduced to $\sim 20 \mathrm{pg} / \mathrm{mL}$ during estrus and diestrus. Estradiol was below the detection limit in OVX mice. Plasma estradiol levels increased to $\sim 120 \mathrm{pg} / \mathrm{mL}$ in OVX mice that received E2 injections for 7 consecutive days.

\subsection{Gender Differences after LMMHA Induces Lung Inflammation after Intratracheal Administration}

Hyaluronic acid fragments (of a molecular mass of $200 \mathrm{kDa}$ ) are common at inflammatory sites in the lung and can induce lung inflammation. LMMHA (200 kDa) activates and attracts neutrophils, which lead to lung inflammation. An intratracheal dose of LMMHA (200 kDa, $65 \mathrm{mg} / \mathrm{kg}$ ) increases total cell (Male: $3.5 \times 10^{5} \pm 0.4 \times 10^{5} / \mathrm{mL}$, Female: $2.7 \times 10^{5} \pm 0.22 \times 10^{5} / \mathrm{mL}$ ) and neutrophil counts (Male: $1.5 \times 10^{5} \pm 0.11 \times 10^{5} / \mathrm{mL}$, Female: $0.9 \times 10^{5} \pm 0.08 \times 10^{5} / \mathrm{mL}$ ) in BALF in both males and females (Figure 1A, B). To further quantify neutrophil sequestration, MPO activity, which reflects the parenchymal infiltrated of neutrophils and macrophages in the lung tissue [18], was measured. These results show an increase in MPO activity in LMMHA-treated mice $12 \mathrm{~h}$ after LMMHA administration (Figure 1C) in both male and female mice, with a greater increase in male mice (Male: $1429 \pm 116 \mathrm{ng} / \mathrm{mL}$, Female: $810 \pm 70 \mathrm{ng} / \mathrm{mL}$ ). Compared to male mice, female mice show reduced thickening of the alveolar septum and reduced infiltration of neutrophils (Figure 1D).

A

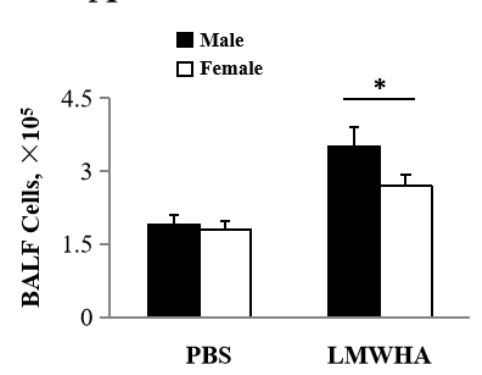

$\mathrm{B}$

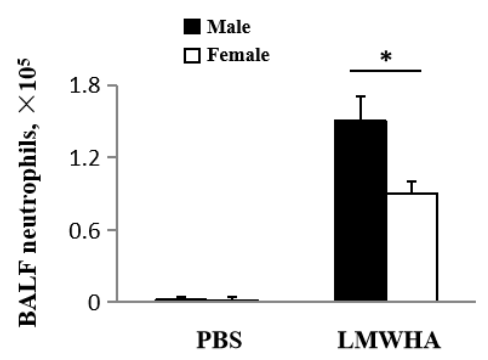

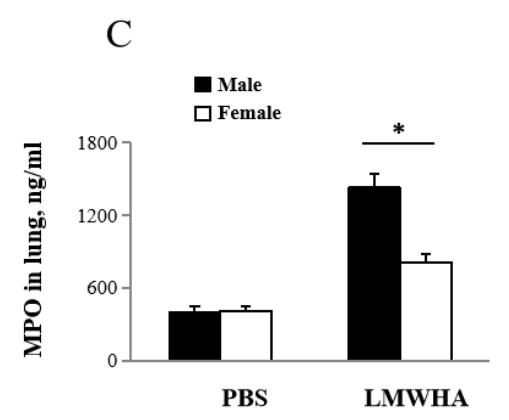

$\mathrm{D}$

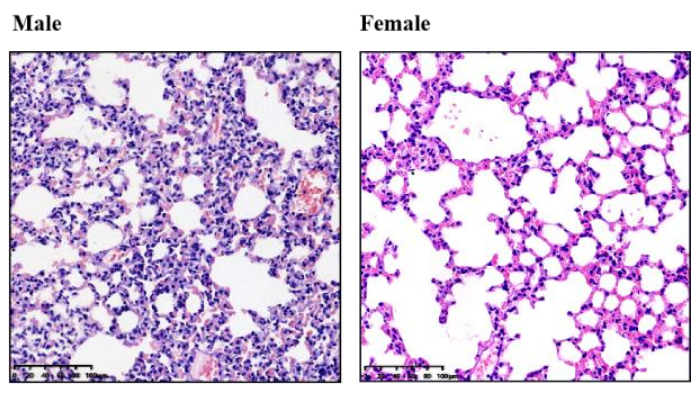

Figure 1. Male mice show greater inflammatory cell infiltration compared to females. $12 \mathrm{~h}$ after intratracheal administration of low molecular mass hyaluronan (LMMHA) (200 kDa, $65 \mathrm{mg} / \mathrm{kg}$ ), (A) total cell and (B) neutrophil counts were performed on BALF. After BALF was performed, (C) MPO of whole lung homogenates was measured, (D) Lung sections were stained with H\&E, original magnification $200 \times$. Values are means \pm SEM from at least five individual animals. Significant differences are indicated by $*, p<0.05$.

\subsection{Differentially Expressed Cytokine Levels in Mice Lungs Induced by LWMHA}

Pro-inflammatory chemokine and cytokine levels in BALF were determined to further quantify LMMHA-triggered inflammatory response. IL-6, an inflammatory marker, delays 
spontaneous apoptosis of neutrophils and enhances the aggregation and adhesion of neutrophils [9]. The levels of IL-6 (Male: $58 \pm 11$ pg/mL, Female: $30 \pm 3$ pg/mL) (Figure 2A), CXCL-1 (Male: $35 \pm 12 \mathrm{pg} / \mathrm{mL}$, Female: $20 \pm 3 \mathrm{pg} / \mathrm{mL}$ ) (Figure 2B), and TNF- $\alpha$ (Male: $33 \pm 6 \mathrm{pg} / \mathrm{mL}$, Female: $10 \pm 4 \mathrm{pg} / \mathrm{mL}$ ) (Figure 2C) were higher in male mice after exposure to LMMHA compared to that of female mice. CXCL-2 is a member of the CXC chemokine family and plays a critical role in the recruitment of neutrophils to tissue damage, infection, and wound recovery sites [19-21]. CXCL-2, secreted by monocytes such as peritoneal and alveolar macrophages [22,23], belongs to the CXC chemokine subfamily ( $\alpha$-chemokines) which are chemoattractants. Previous studies have also shown that CXCL-2 helps recruit neutrophils in the development of inflammation and tissue injury [24,25]. Our results show (Figure 2D) that CXCL-2 activities are dramatically higher in the male group (Male: $21 \pm 5 \mathrm{pg} / \mathrm{mL}$, Female: $11 \pm 2 \mathrm{pg} / \mathrm{mL}$ ). Hence, intratracheal administration of LMMHA leads to clear gender differences in mice lung inflammation.
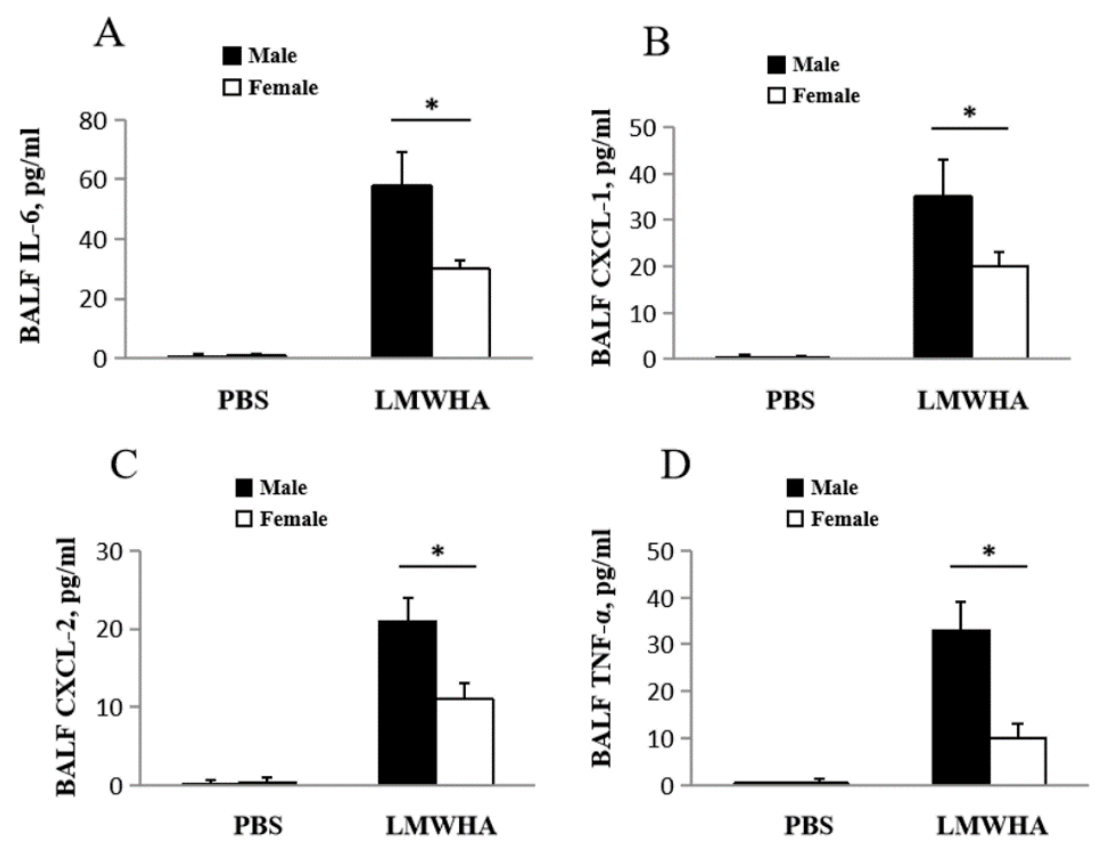

Figure 2. Male mice have a higher level of inflammatory cytokine production compared to that of females $12 \mathrm{~h}$ after intratracheal administration of LMWHA (200 kDa, $65 \mathrm{mg} / \mathrm{kg}$ ). (A) IL-6, (B) CXCL-1, (C) CXCL-2, and (D) TNF- $\alpha$ in BALF were analyzed. Values are means \pm SEM from at least five individual animals. Significant differences are indicated by ${ }^{*}, p<0.05$.

\subsection{Estradiol Effects on LMMHA-Induced Lung Injury}

To determine the role of estrogen in lung inflammation, we evaluated if E2 can mimic regulatory functions of ovariectomized mice in acute lung injury. These results show that compared to OVX mice, alveolar septum thickening and neutrophil infiltration is reduced in those mice that have an E2 supplement (Figure 3A). Lung injury score was significantly decreased in E2 treated OVX mice on quantal scoring of histological lung injury severity (Figure 3B). OVX mice treated with E2 show significantly reduced neutrophil counts in BALF compared to that of LMMHA-treated OVX mice (Intact: $0.85 \times 10^{5} \pm 0.08 \times 10^{5} / \mathrm{mL}$, OVX: $1.4 \times 10^{5} \pm 0.1 \times 10^{5} / \mathrm{mL}$, OVX + E2: $\left.0.9 \times 10^{5} \pm 0.11 \times 10^{5} / \mathrm{mL}\right) 12 \mathrm{~h}$ after LMMHA administration (Figure $3 \mathrm{C}$ ). OVX mice treated with E2 demonstrate less intense MPO activity in the lung tissue compared with OVX mice (Intact: $815 \pm 75 \mathrm{ng} / \mathrm{mL}$, OVX: $1300 \pm 150 \mathrm{ng} / \mathrm{mL}, \mathrm{OVX}+\mathrm{E} 2: 900 \pm 100 \mathrm{ng} / \mathrm{mL}$ ) (Figure 3D). 
A

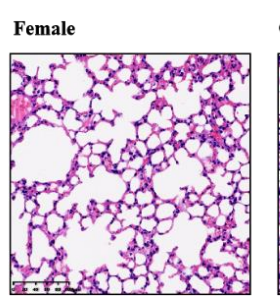

ovx

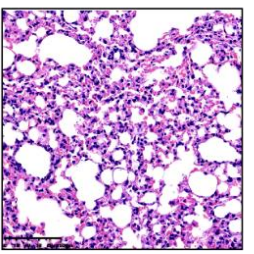

C

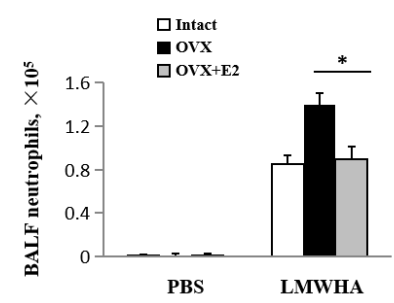

B Female

ZD OVX
$\square$ OVX+E2

OVX+E2
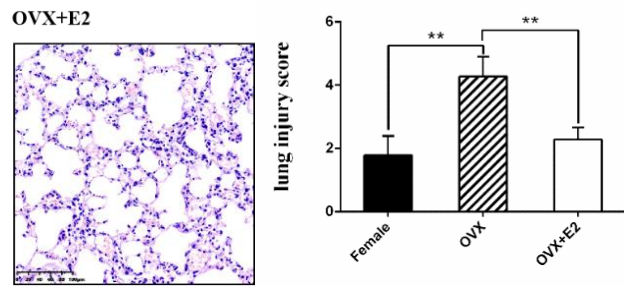

$\mathrm{D}$

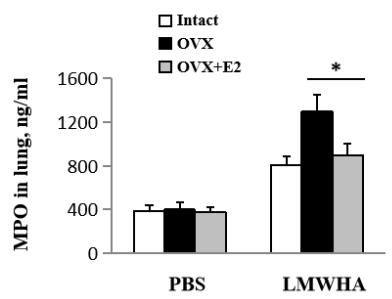

Figure 3. Effects of OVX mice treated with 17 $\beta$-estradiol (E2) on inflammatory cell infiltration. After a recovery period of at least two weeks, each OVX mouse received daily subcutaneous injection of either vehicle (sesame oil, $2 \mathrm{~mL} / \mathrm{kg} \mathrm{BW}$ ) or E2 (twice a day, $3 \mu \mathrm{g} / \mathrm{kg} \mathrm{BW}$ ) for one week. (A) Lung sections stained with H\&E, original magnification $200 \times$. Values are means \pm SEM from at least five individual animals, (B) Lung injury score, (C) total cell counts, and (D) neutrophil counts were performed on BALF $12 \mathrm{~h}$ after intratracheal administration of LMWHA (200 kDa, $65 \mathrm{mg} / \mathrm{kg})$. Significant differences are indicated by $*, p<0.05$.

Compared to OVX mice, E2-treated OVX mice show significantly reduced lung IL-6 levels (Intact: $30 \pm 2.5 \mathrm{pg} / \mathrm{mL}$, OVX: $55 \pm 3$ pg/mL, OVX + E2: $32 \pm 4 \mathrm{pg} / \mathrm{mL}$ ) (Figure 4A), CXCL-1 (Intact: $19 \pm 3 \mathrm{pg} / \mathrm{mL}$, OVX: $33 \pm 6 \mathrm{pg} / \mathrm{mL}, \mathrm{OVX}+\mathrm{E} 2: 21 \pm 5 \mathrm{pg} / \mathrm{mL}$ ) (Figure 4B), CXCL-2 (Intact: $11 \pm 1 \mathrm{pg} / \mathrm{mL}, \mathrm{OVX}: 30 \pm 5 \mathrm{pg} / \mathrm{mL}, \mathrm{OVX}+\mathrm{E} 2: 12 \pm 2 \mathrm{pg} / \mathrm{mL}$ ) (Figure 4C), TNF- $\alpha$ (Intact: $10 \pm 1 \mathrm{pg} / \mathrm{mL}$, OVX: $31 \pm 4 \mathrm{pg} / \mathrm{mL}, \mathrm{OVX}+\mathrm{E} 2: 15 \pm 4 \mathrm{pg} / \mathrm{mL}$ ) (Figure $4 \mathrm{D}$ ) $12 \mathrm{~h}$ after LMMHA administration.
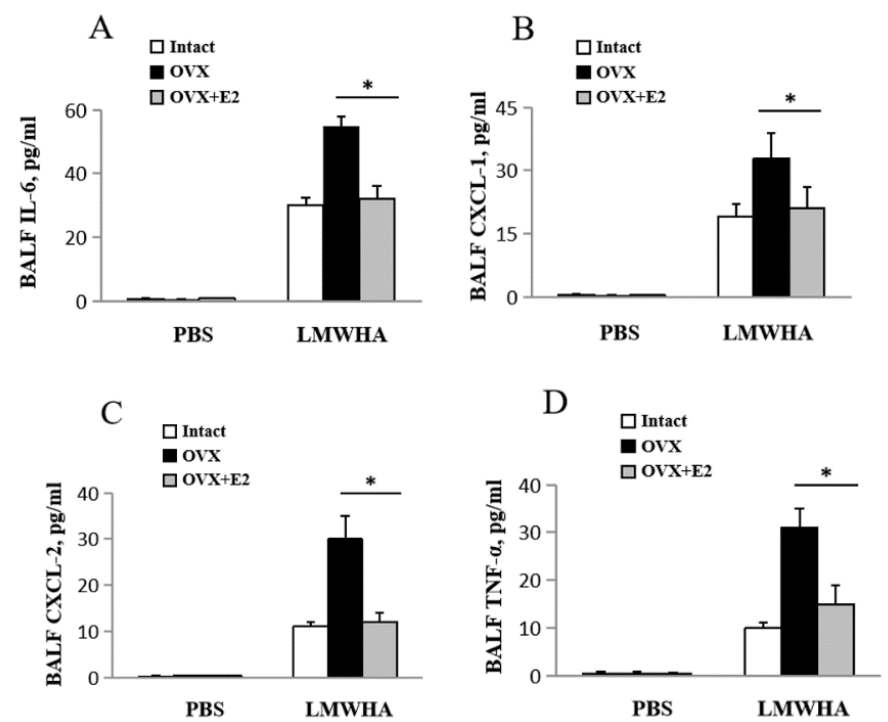

Figure 4. Effects of OVX mice treated with $17 \beta$-estradiol (E2) on inflammatory cytokine production. After a recovery period of at least two weeks, each OVX mouse received daily subcutaneous injection of either vehicle (sesame oil, $2 \mathrm{~mL} / \mathrm{kg} \mathrm{BW}$ ) or E2 (twice a day, $3 \mu \mathrm{g} / \mathrm{kg} \mathrm{BW}$ ) for one week. (A) IL-6, (B) CXCL-1, (C) CXCL-2, and (D) TNF- $\alpha$ in BALF were analyzed $12 \mathrm{~h}$ after intratracheal administration of LMWHA (200 kDa, $65 \mathrm{mg} / \mathrm{kg})$. Values are means \pm SEM from at least five individual animals. Significant differences are indicated by ${ }^{*}, p<0.05$. 


\section{Discussion}

In this study, we demonstrate that male mice develop greater lung inflammation than female mice after intratracheal administration of LMMHA. Ovariectomized females exhibit increased inflammation compared to females with intact ovaries. Furthermore, $17 \beta$-estradiol injection into ovariectomized female mice reduces inflammation. Therefore, $17 \beta$-estradiol may be a key contributor to disparate gender effects in LMMHA induced inflammation. These findings agree with previous clinical studies in which female mice have reduced morbidity and mortality due to ischemia/reperfusion, trauma, sepsis, and shock, which are common risk factors for ALI $[13,14,26,27]$. Administration of $17 \beta$-estradiol limits neutrophil infiltration and subsequent tissue destruction in liver trauma [28,29], carrageenan-induced pleurisy, tracheal LPS damage [17,30], and OVA-induced allergic reaction [31]. Since neutrophils contribute to the acute phase of inflammation and recruit other innate immune system players, $17 \beta$-estradiol suppression of neutrophil activity could have impressive effects on immune response.

Neutrophils are key mediators of inflammatory response, particularly in LMMHAinduced lung injury [10]. The process of neutrophil extravasation involves multiple subsequent steps of margination and rolling, adhesion, diapedesis, and migration. The steps of margination and rolling are mediated by E-selection and P-selectin on the vasculature, which bind to Sialyl Lewis on the neutrophil. This interaction allows leukocytes to travel to areas of need in the body before tightly binding to endothelial cells (through intracellular adhesion molecule 1, ICAM-1) and traveling between endothelial cells to the site of injury. Previous studies have shown that P-selectin is at its lowest during the luteal phase in women and that an intramuscular $17 \beta$-estradiol injection significantly lowers soluble P-selectin levels in healthy males [32]. Ovariectomized mice demonstrate an increase in neutrophil accumulation compared to that of cycling animals, and $17 \beta$-estradiol inhibits LMMHA induced lung inflammatory responses. Our study implicates endogenous $17 \beta-$ estradiol in the regulation of neutrophil infiltration by controlling the levels of P-selectin and ICAM-1 in lung tissue injury.

Neutrophils are removed by apoptosis and macrophage phagocytosis from areas of tissue injury, leading to resolution of inflammation [33]. This process is particularly important in the resolution of lung inflammation. Disruption to the neutrophil apoptosis process can lead to acute respiratory distress syndrome (ARDS) and sepsis [34]. Neuronal, cardiac, and renal ischemia are additionally subject to sex-specific differences in apoptosis [35-37]. $17 \beta$-estradiol may also inhibit the accumulation of LMMHA treated neutrophils in lung by impairing their survival.

Differences between LMMHA-induced neutrophil infiltration in males and females could be the result of sex specific alterations in the neutrophil estrogen receptor (ER) phenotype: expression of ER subtypes depends on exposure of neutrophils to estrogen. Men and premenopausal women express ER $\alpha$ and ER $\beta$ neutrophil subtypes. Ovulation in women increases estrogen and upregulates ER $\alpha$ and ER $\beta$. The follicular phase of the menstrual cycle is associated with low estrogen, but in vitro incubation of follicular phase neutrophils with $17 \beta$-estradiol leads to similar upregulation of the ER $\alpha$ and $\operatorname{ER} \beta$ subtypes [38]. Interestingly, only the ER $\alpha$ subtype is upregulated when neutrophils from men are incubated with $17 \beta$-estradiol, which suggests sex-differences of ER $\alpha$ and ER $\beta$ subtypes expression [38]. These differences may explain why neutrophils from men have reduced neutrophil adhesion [39]. ER $\alpha$ is an important facilitator of the inflammatory response in many types of tissue through its effects on estrogen such as in alveolar regeneration [40-44]. On the other hand, ER $\beta$ plays a role in trauma-hemorrhage induced lung injury [45], but ER $\beta$ agonists do not impact the lung inflammatory response [46]. Further studies are needed to determine how ER $\alpha$ and ER $\beta$ lead to these effects on LMMHA-treated neutrophil functionality.

Previous studies show that inhibition of PI3K or genetic deletion of Akt1 enhances LMMHA-induced apoptosis of neutrophils. Phosphorylation of p38 and ERK1/2 was significantly decreased in $\mathrm{Akt1}^{-/-}$mice neutrophils treated with LMMHA [12]. Adminis- 
tration of $17 \beta$-estradiol after trauma-hemorrhage prevents phosphorylation of Kupffer cell p38 MAPK and normalizes Kupffer cell production of IL-6, TNF- $\alpha$, MIP-1 $\alpha$, and CXCL-2. Further studies are needed to investigate whether $17 \beta$-estradiol prevents the increase in neutrophil infiltration and cytokine production via PI3K, Akt, and p38MARK after LMMHA administration.

\section{Materials and Methods}

\subsection{Mice and Model Description}

C57BL/ 6 mice aged 6-8 weeks were obtained from the Zhejiang Academy of Medical Sciences. All experiments were approved by the laboratory animals ethical committee of the Zhejiang University of Technology and followed the NIH guide for laboratory animals (NIH Publication No. 85-23, revised 1996) for the care and use of animals. Mice were maintained under specific pathogen-free conditions and given access to food and water. To obtain mice at known stages of the estrous cycle, vaginal smears were examined daily. Mice have 4 or 5-day estrous cycles, and only mice with at least two consecutive 4-day cycles were used. LMMHA $(200 \mathrm{kDa}, 65 \mathrm{mg} / \mathrm{kg})$ was administered to the trachea with a microsprayer (Penn-Century, Wyndmoor, PA, USA) [16].

\subsection{Ovariectomized (OVX)}

The lower abdomen of ether-anesthetized mice was sliced, and ovaries were removed. The abdominal tissue was sutured, and an intramuscular injection of Pentantibiotic $(570 \mathrm{mg} / \mathrm{kg}$ ) was made. Vaginal smear cellular morphology was analyzed to determine the effectiveness of OVX after 7 days. After a recovery period of at least two weeks, OVX mice received subcutaneous injection of either vehicle (sesame oil, $2 \mathrm{~mL} / \mathrm{kg} \mathrm{BW}$ ) or E2 (17 $\beta$-estradiol, twice a day, $3 \mu \mathrm{g} / \mathrm{kg} \mathrm{BW}$ ) for one week. The experimental protocol was approved by the Laboratory Animals Ethical Committee of Zhejiang University of Technology (11 May 2020) and was registered on the Zhejiang University of Technology Animal Protocols Register (20200512053, 11 May 2020).

\subsection{Bronchoalveolar Lavage Fluid (BALF)}

Mice were sacrificed $12 \mathrm{~h}$ after intratracheal administration of LMWHA (200 kDa, $65 \mathrm{mg} / \mathrm{kg}$ ). A midline incision was used to expose the trachea, which was then cannulated with a sterile 22-gauge needle. A total of $0.5 \mathrm{~mL}$ of cold PBS was injected and retrieved through the midline incision four times for a total of $1.8 \mathrm{~mL}$ BALF collected per mouse. The samples were then centrifuged, and sample supernatants of were stored at $-80^{\circ} \mathrm{C}$. A hemocytometer was used to count total cell numbers in BALF samples. BALF neutrophil counts were determined using cytospin preparations stained with the Diff-Quick staining kit (IMEB, San Marcos, CA, USA).

\subsection{ELISA}

IL-6, TNF- $\alpha$, CXCL-1, and CXCL-2 levels in BALF were quantified with mouse ELISA assay kits (R\&D Systems, Minneapolis, MN, USA) as per the manufacturer's protocol. 17 $\beta$ estradiol levels in plasma were measured using a high sensitivity ELISA kit (ADI-900-174, Enzo Life Sciences).

\subsection{Myeloperoxidase Assay}

After BALFs were obtained, whole-lung homogenates were measured using a mouse myeloperoxidase (MPO) ELISA kit (Cell Sciences, Canton, MA, USA) per manufacturer protocol.

\subsection{Lung Injury Score}

Lung inflammation was assessed as described previously [10]. Blinded quantal injury assessment was performed through evaluation of alveolar septae, alveolar hemorrhage, intra-alveolar fibrin, and intra-alveolar infiltrates. A $10 \%$ buffered formalin was used to 
fix lung tissues overnight. These sections then underwent H\&E staining: dehydration, clearing, and embedding in paraffin. At minimum, five fields were examined per section.

\subsection{Statistical Analysis}

Data from at least three independent experiments are expressed as mean $\pm \mathrm{SEM}$. In comparisons of two groups, a Student's paired two-tailed $t$-test was used.

\section{Conclusions}

Our results illustrate the role of ovarian hormones and exogenous estrogen in modulation of lung injury and neutrophil accumulation in LMMHA-injured lungs. In addition, IL-6, CXCL-1, TNF- $\alpha$, and CXCL-2 have been shown to enhance the inflammatory response in OVX and male mice. Finally, they show that $17 \beta$-estradiol can be considered as a therapy for reducing lung inflammation.

Author Contributions: Conceptualization, H.Z.; methodology, Y.X., D.X., and B.L.; investigation, Y.X., D.X., and B.L.; writing-original draft preparation, Y.X.; writing-review and editing, Y.X., D.X., B.L., and H.Z.; funding acquisition, H.Z. All authors have read and agreed to the published version of the manuscript.

Funding: This research was funded by the National Natural Science Foundation of China, No.81870063 and Zhejiang Natural Science Foundation of China, LY18H010009.

Institutional Review Board Statement: All experiments were approved by the laboratory animals ethical committee of the Zhejiang University of Technology and followed the NIH guide for laboratory animals (NIH Publication No. 85-23, revised 1996) for the care and use of animals. The experimental protocol was approved by the Laboratory Animals Ethical Committee of Zhejiang University of Technology (11 May 2020) and was registered on the Zhejiang University of Technology Animal Protocols Register (20200512053, 11 May 2020).

Data Availability Statement: The data that support the findings of this study are available from the corresponding author upon reasonable request.

Conflicts of Interest: The authors declare no conflict of interest.

\begin{tabular}{ll}
\multicolumn{2}{l}{ Abbreviations } \\
LMMHA & Low molecular mass hyaluronan \\
IL-6 & Interleukin-6 \\
TNF- $\alpha$ & Tumor necrosis factor $\alpha$ \\
CXCL-1 & Chemokine (C-X-C motif) ligand 1 \\
CXCL-2 & Chemokine (C-X-C motif) ligand 2 \\
OVX & Ovariectomized \\
ALI & Acute lung injury \\
HA & Hyaluronan \\
BALF & Bronchoalveolar Lavage Fluid \\
MPO & Myeloperoxidase \\
E2 & 17 $\beta$-estradiol \\
ARDS & Acute Respiratory Distress Syndrome
\end{tabular}

\section{References}

1. Weissmann, B.; Meyer, K.; Sampson, P.; Linker, A. Isolation of oligosaccharides enzymati- cally produced from hyaluronic acid. J. Biol. Chem. 1954, 208, 417-429. [PubMed]

2. Lauer, M.E.; Dweik, R.A.; Garantziotis, S.; Aronica, M.A. The Rise and Fall of Hyaluronan in Respiratory Diseases. Int. J. Cell Biol. 2015, 2015, 712507. [CrossRef] [PubMed]

3. Nakamura, Y.; Suzuki, R.; Mizuno, T.; Abe, K.; Yamauchi, K. Therapeutic implication of genetic variants of IL13 and STAT4 in airway remodelling with bronchial asthma. Clin. Exp. Allergy 2016, 46, 1152-1161. [CrossRef] [PubMed]

4. Papakonstantinou, E.; Roth, M.; Klagas, I.; Karakiulakis, G.; Tamm, M.; Stolz, D. COPD Exacerbations are Associated with Proinflammatory Degradation of Hyaluronic Acid. Chest 2015, 148, 1497-1507. [CrossRef]

5. Li, Y.; Jiang, D.; Liang, J.; Meltzer, E.B.; Gray, A.; Miura, R.; Wogensen, L.; Yamaguchi, Y.; Noble, P.W. Severe lung fibrosis requires an invasive fibroblast phenotype regulated by hyaluronan and CD44. J. Exp. Med. 2011, 208, 1459-1471. [CrossRef] 
6. Kredel, M.; Muellenbach, R.M.; Brock, R.W.; Wilckens, H.; Brederlau, J.; Roewer, N.; Wunder, C. Liver dysfunction after lung recruitment manoeuvres during pressure-controlled ventilation in experimental acute respiratory distress. Crit. Care 2007, 11, R13. [CrossRef]

7. Jiang, D.; Liang, J.; Noble, P.W. Hyaluronan in tissue injury and repair. Annu. Rev. Cell Dev. Biol. 2007, 23, 435-461. [CrossRef]

8. Ottonello, L.; Frumento, G.; Arduino, N.; Bertolotto, M.; Dallegri, F. Differential regulation of spontaneous and immune complex-induced neutrophil apoptosis by proinflammatory cytokines. J. Leukocyte Biol. 2002, 72, 125-132.

9. Taylor, K.R.; Trowbridge, J.M.; Rudisill, J.A.; Termeer, C.C.; Simon, J.C.; Gallo, R.L. Hyaluronan fragments stimulate endothelial recognition of injury through TLR4. J. Biol. Chem. 2004, 279, 17079-17084. [CrossRef]

10. Leu, S.W.; Shi, L.; Xu, C.; Zhao, Y.; Liu, B.; Li, Y.; Shiedlin, A.; Xiang, C.; Shen, H.; Quinn, D.A.; et al. TLR4 through IFN-b Promotes Low Molecular Mass Hyaluronan-Induced Neutrophil Apoptosis. J. Immunol. 2011, 186, 556-562. [CrossRef]

11. Zhao, H.; Leu, S.W.; Shi, L.; Shi, L.; Dedaj, R.; Zhao, G.; Garg, H.; Shen, L.; Lien, E.; Fitzgerald, K.A.; et al. TLR4 is a negative regulator in noninfectious lung inflammation. J. Immunol. 2010, 184, 5308-5314. [CrossRef] [PubMed]

12. Zhao, H.; Ma, Y.; Zhang, L. Low-molecular-mass hyaluronan induces pulmonary inflammation by up-regulation of Mcl-1 to inhibit neutrophil apoptosis via PI3K/Akt1 pathway. Immunology 2018, 155, 387-395. [CrossRef] [PubMed]

13. Phua, J.; Badia, J.R.; Adhikari, N.K.; Friedrich, J.O.; Fowler, R.A.; Singh, J.M.; Scales, D.C.; Stather, D.R.; Li, A.; Jones, A.; et al. Has mortality from acute respiratory distress syndrome decreased over time?: A systematic review. Am. J. Respir. Crit. Care Med. 2009, 179, 220-227. [CrossRef] [PubMed]

14. Agarwal, R.; Aggarwal, A.N.; Gupta, D.; Behera, D.; Jindal, S.K. Etiology and outcomes of pulmonary and extrapulmonary acute lung injury/ARDS in a respiratory ICU in North India. Chest 2006, 130, 724-729. [CrossRef]

15. Moss, M.; Mannino, D.M. Race and gender differences in acute respiratory distress syndrome deaths in the United States An analysis of multiple-cause mortality data (1979-1996). Crit. Care Med. 2002, 30, 1679-1685. [CrossRef]

16. Thais Fantozzi, E.; Rodrigues-Garbin, S.; Yamamoto Ricardo-da-Silva, F.; Martins Oliveira-Filho, R.; Spina, D.; Tavares-de-Lima, W.; Riffo-Vasquez, Y. Acute lung injury induced by intestinal ischemia and reperfusion is altered in obese female mice. Pulm. Pharmacol. Ther. 2018, 49, 54-59. [CrossRef]

17. Speyer, C.L.; Rancilio, N.J.; McClintock, S.D.; Crawford, J.D.; Ward, P.A. Regulatory effects of estrogen on acute lung inflammation in mice. Am. J. Physiol. Cell Physiol. 2005, 288, C881-C890. [CrossRef]

18. Tang, Y.; Chen, Y.; Chu, Z.; Yan, B.; Xu, L. Protective effect of cryptotanshinone on lipopolysaccharide-induced acute lung injury in mice. Eur. J. Pharmacol. 2014, 723, 494-500. [CrossRef]

19. Tsujimoto, H.; Ono, S.; Mochizuki, H.; Aosasa, S.; Matsumoto, A. Role of Macrophage Inflammatory Protein 2 in Acute Lung Injury in Murine Peritonitis. J. Surg. Res. 2002, 103, 61-67. [CrossRef]

20. Closa, D. Activation of alveolar macrophages in lung injury associated with experimental acute pancreatitis is mediated by the liver. Ann. Surg. 1999, 229, 230-236. [CrossRef]

21. Lentsch, A.B.; Yoshidome, H.; Cheadle, W.G.; Miller, F.N.; Edwards, M. Chemokine involvement in hepatic ischemia/reperfusion injury in mice: Roles for macrophage inflammatory protein-2 and KC. Hepatology 1998, 27, 1172-1177. [CrossRef] [PubMed]

22. Xing, Z.; Jordana, M.; Kirpalani, H.; Driscoll, K.E.; Schall, T.J.; Gauldie, J. Cytokine expression by neutrophils and macrophages in-vivo-endotoxin induces tumor-necrosis-factor-alpha, macrophage inflammatory protein-2, interleukin-1-beta, and interleukin-6 but not rantes or transforming growth factor-beta(1) messenger-rna expression in acute lung inflammation. Am. J. Respir. Cell Mol. Biol. 1994, 10, 148-153. [PubMed]

23. Greenberger, M.J.; Strieter, R.M.; Kunkel, S.L.; Danforth, J.M.; Laichalk, L.L.; Mcgillicuddy, D.C.; Standiford, T.J. Neutralization of macrophage inflammatory protein-2 attenuates neutrophil recruitment and bacterial clearance in murine Klebsiella pneumonia. Infect. Immun. 1996, 173, 159-165. [CrossRef] [PubMed]

24. Angele, M.K.; Knferl, M.W.; Schwacha, M.G.; Ayala, A.; Chaudry, I.H. Hemorrhage decreases macrophage inflammatory protein 2 and interleukin-6 release A possible mechanism for increased wound infection. Ann. Surg. 1999, 229, 651-660. [CrossRef]

25. Schmal, H.; Shanley, T.P.; Jones, M.L.; Friedl, H.P.; Ward, P.A. Role for macrophage inflammatory protein-2 in lipopolysaccharideinduced lung injury in rats. J. Immunol. 1996, 156, 1963-1972.

26. Anadkat, J.S.; Kuzniewicz, M.W.; Chaudhari, B.P.; Cole, F.S.; Hamvas, A. Increased risk for respiratory distress among white, male, late preterm and term infants. J. Perinatol. 2012, 32, 780-785. [CrossRef]

27. Lahm, T.; Crisostomo, P.R.; Markel, T.A.; Wang, M.; Weil, B.R.; Novotny, N.M.; Meldrum, D.R. The effects of estrogen on pulmonary artery vasoreactivity and hypoxic pulmonary vasoconstriction: Potential new clinical implications for an old hormone. Crit. Care Med. 2008, 36, 2174-2183. [CrossRef]

28. Frink, M.; Thobe, B.M.; Hsieh, Y.C.; Choudhry, M.A.; Schwacha, M.G.; Bland, K.I.; Chaudry, I.H. 17-Estradiol inhibits keratinocytederived chemokine production following trauma-hemorrhage. Am. J. Physiol. Lung Cell Mol. Physiol. 2007, $292,585-591$. [CrossRef]

29. Hsieh, Y.C.; Frink, M.; Hsieh, C.H.; Choudhry, M.A.; Schwacha, M.G.; Bland, K.I.; Chaudry, I.H. Downregulation of migration inhibitory factor is critical for estrogen-mediated attenuation of lung tissue damage following trauma-hemorrhage. Am. J. Physiol. Lung Cell Mol. Physiol. 2007, 292, 1227-1232. [CrossRef]

30. Cuzzocrea, S.; Santagati, S.; Sautebin, L.; Mazzon, E.; Calabro, G.; Serraino, I.; Caputi, A.P.; Maggi, A. 17-Estradiol antiinflammatory activity in carrageenan-induced pleurisy. Endocrinology 2000, 141, 1455-1463. [CrossRef] 
31. De Oliveira, A.P.; Peron, J.P.; Damazo, A.S.; Franco, A.L.; Domingos, H.V.; Oliani, S.M.; Oliveira-Filho, R.M.; Vargaftig, B.B.; Tavares-de-Lima, W. Female sex hormones mediate the allergic lung reaction by regulating the release of inflammatory mediators and the expression of lung E-selectin in rats. Respir. Res. 2010, 11, 115. [CrossRef] [PubMed]

32. Warren, J.S.; Yabroff, K.R.; Mandel, D.M.; Johnson, K.J.; Ward, P.A. Role of O2 in neutrophil recruitment into sites of dermal and pulmonary vasculitis. Free Radic. Biol. Med. 1990, 8, 163-172. [CrossRef]

33. Savill, J.; Dransfield, I.; Gregory, C.; Haslett, C. A blast from the past: Clearance of apoptotic cells regulates immune responses. Nat. Rev. Immunol. 2002, 2, 965-975. [CrossRef] [PubMed]

34. Matute-Bello, G.; Liles, W.C.; Radella II, F.; Steinberg, K.P.; Ruzinski, J.T.; Jonas, M.; Chi, E.Y.; Hudson, L.D.; Martin, T.R. Neutrophil apoptosis in the acute respiratory distress syndrome. Am. J. Respir. Crit. Care Med. 1997, 156, 1969-1977. [CrossRef] [PubMed]

35. Hutchens, M.P.; Dunlap, J.; Hurn, P.D.; Jarnberg, P.O. Renal ischemia: Does sex matter? Anesth. Anal. 2008, 107, 239-249. [CrossRef] [PubMed]

36. Lang, J.T.; McCullough, L.D. Pathways to ischemic neuronal cell death: Are sex differences relevant? J. Transl. Med. 2008, 6, 33. [CrossRef] [PubMed]

37. Dunlay, S.M.; Roger, V.L. Gender Differences in the Pathophysiology, Clinical Presentation, and Outcomes of Ischemic Heart Failure. Curr. Heart. Fail Rep. 2012, 9, 267-276. [CrossRef]

38. Laura, M.; Margarita, G.; Joaguin, D.; Luis, R.; Santos, C.; Antonio, L. Expression of estrogen receptor subtypes and neuronal nitric oxide synthase in neutrophils from women and men: Regulation by estrogen. Cardiovasc. Res. 2002, 56, 43-51.

39. Garcia-Duran, M.; de Frutos, T.; Diaz-Recasens, J.; Garcia-Galvez, G.; Jimenez, A.; Monton, M.; Farre, J.; de Miguel, L.S.; Gonzalez-Fernandez, F.; Arriero, M.D.; et al. Estrogen stimulates neuronal nitric oxide synthase protein expression in human neutrophils. Circ. Res. 1999, 85, 1020-1026. [CrossRef]

40. Dubal, D.B.; Zhu, H.; Yu, J.; Rau, S.W.; Shughrue, P.J.; Merchenthaler, I.; Kindy, M.S.; Wise, P.M. Estrogen receptor alpha, not beta, is a critical link in estradiol-mediated protection against brain injury. Proc. Natl. Acad. Sci. USA 2001, 98, 1952-1957. [CrossRef]

41. Vegeto, E.; Belcredito, S.; Etteri, S.; Ghisletti, S.; Brusadelli, A.; Meda, C.; Krust, A.; Dupont, S.; Ciana, P.; Chambon, P.; et al. Estrogen receptor-mediates the brain antiinflammatory activity of estradiol. Proc. Natl. Acad. Sci. USA 2003, 100, 9614-9619. [CrossRef] [PubMed]

42. Polanczyk, M.; Yellayi, S.; Zamora, A.; Subramanian, S.; Tovey, M.; Vandenbark, A.A.; Offner, H.; Zachary, J.F.; Fillmore, P.D.; Blankenhorn, E.P.; et al. Estrogen receptor-1 (Esr1) and -2 (Esr2) regulate the severity of clinical experimental allergic encephalomyelitis in male mice. Am. J. Pathol. 2004, 164, 1915-1924. [CrossRef]

43. Brouchet, L.; Krust, A.; Dupont, S.; Chambon, P.; Bayard, F.; Arnal, J.F. Estradiol accelerates reendothelialization in mouse carotid artery through estrogen receptor- $\alpha$ but not estrogen receptor- $\beta$. Circulation 2001, 103, 423-428. [CrossRef] [PubMed]

44. Massaro, D.; Clerch, L.B.; Massaro, G.D. Estrogen receptor- $\alpha$ regulates pulmonary alveolar loss and regeneration in female mice: Morphometric and gene expression studies. Am. J. Physiol. Lung Cell Mol. Physiol. 2007, 293, 222-228. [CrossRef] [PubMed]

45. Yu, H.P.; Hsieh, Y.C.; Suzuki, T.; Shimizu, T.; Choudhry, M.A.; Schwacha, M.G.; Chaudry, I.H. Salutary effects of estrogen receptor- $\alpha$ agonist on lung injury after trauma-hemorrhage. Am. J. Physiol. Lung Cell Mol. Physiol. 2006, 290, 1004-1009. [CrossRef] [PubMed]

46. Catley, M.C.; Birrell, M.A.; Hardaker, E.L.; de Alba, J.; Farrow, S.; Haj-Yahia, S.; Belvisi, M.G. Estrogen receptor $\alpha$ : Expression profile and possible anti-inflammatory role in disease. J. Pharmacol. Exp. Ther. 2008, 326, 83-88. [CrossRef] 